\title{
A New Human Highly Tumorigenic Neuroblastoma Cell Line with Undetectable Expression of $\mathrm{N}-\mathrm{myc}^{1}$
}

\author{
P. CORNAGLIA-FERRARIS, M. PONZONI, P. MONTALDO, G. L. MARIOTTINI, E. DONTI, \\ D. DI MARTINO, AND G. P. TONINI \\ Pediatric Oncology Research Laboratory, G. Gaslini Children's Hospital, Via 5 Maggio 39, 16148 Genoa \\ [P.C.F., M.P., P.M., G.L.M., D.D.M., G.P.T.]; and Laboratory of Cytogenetics, Department of Internal \\ Medicine, University of Perugia, 06100 Perugia, Italy [E.D.]
}

\begin{abstract}
A peculiar human cell line (GI-ME-N) derived from the metastatic bone marrow of a 2 -yr-old patient with stage IV neuroblastoma (NB) was extensively characterized. Cell-type-specific markers, tumorigenicity in nude mice, morphology, cytogenetics, and amplification/ expression of the $\mathrm{N}$-myc gene were evaluated. All metaphases presented the typical $1 p$ deletion. Surface markers specific for NB cells, vimentin, and neurofilament proteins were all clearly detectable with immunofluorescence and/ or western blot procedures. Moreover, it was found that GI-ME-N cells did not express N-myc oncogene or HLA class 1 antigens, and were not classified as peripheral neuroectodermal tumor cells. However, extremely short latency and survival times, comparable to peripheral neuroectodermal tumor cells, were observed in nude mice grafted with GI-ME-N. In addition, no correlations were observed in tumorigenicity of $\mathrm{N}$-myc amplified (IMR32) versus unamplified (SK-N-SH GI-ME-N) human NB cell lines in nude mice. We conclude that $\mathrm{N}$-myc amplification/ expression do not correlate with the aggressiveness of human NB in athymic animals, which is not always explained by the peripheral neuroectodermal tumor cell nature of the malignant cells, either. (Pediatr Res 27: 1-6, 1990)
\end{abstract}

\section{Abbreviations}

$\mathrm{NB}$, neuroblastoma

GI-ME-N, Gaslini Institute, patient initials, neuroblastoma

PNET, peripheral neuroectodermal tumor

BM, bone marrow

s.c., subcutaneous

Neuroblastoma, a neoplasm of the sympathetic nervous system, is the most common extracranial solid tumor arising in children $(1,2)$. In contrast to other pediatric tumors, the prognosis of NB patients has not significantly improved in the last 10 yr. With conventional chemotherapy, including local irradi-

Received November 25, 1988; accepted August 15, 1989.

Correspondence and reprint requests P. Cornaglia-Ferraris, M.D., Pediatric Oncology Research Laboratory, G. Gaslini Children's Hospital, Via 5 Maggio 39, 16148 Genoa, Italy.

Supported by A.I.R.C., Italian Association for Cancer Research, Milan and G. Gaslini grant 871703F.3

${ }^{1}$ GI-ME-N cells are available upon request to: P. Durand, M.D., Scientific Director, G. Gaslini Children's Hospital, Via 5 Maggio 39, 16148 Genoa, Italy. ation and surgery, the long-term survival for all metastatic forms of the disease does not exceed $20 \%$ (3). Intense chemotherapy, followed by the infusion of anti-CD3 IL-2-activated killer cells (4), or total body irradiation followed by autologous bone marrow transplantation have recently improved the disease-free survival $(1,3,5)$. However, clinical relapses with disease progression are observed in at least $70 \%$ of treated patients (5).

Such frustrating clinical results have stimulated basic research aiming to develop new prognostic and diagnostic criteria (6-8) as well as new therapeutic strategies (9-11). A significant correlation between the amplification of the N-myc oncogene and poor prognosis has been reported by Seeger et al. (6), and subsequently confirmed $(8,12)$. However, some clinical exceptions have been described $(13,14)$. Continuous human NB cell lines have become important in vitro models for this type of tumor $(9,10,15,16)$. A biologic classification of cell lines derived from human extracranial neural tumors has been recently proposed (17). These authors showed that the time necessary for observing a 5-mm s.c. tumor in nude mice injected with a large number of human NB cells (lag time) was significantly shorter for N-myc nonamplified cells showing high HLA expression. However, NB cell lines virtually lacking HLA class I Ag, whether or not expressing high levels of $\mathrm{N}$-myc oncogene, would have very long lag times. It was concluded that $\mathrm{N}$-myc nonamplified cell lines can be subdivided according to tumorigenicity in PNET (HLA +, N-myc-, c-myc \pm ) and "true" NB (HLA-, N-myc \pm , cmyc-).

We describe a new human NB cell line, GI-ME-N, established from a BM sample of a 2-yr-old white girl with stage IV NB (1). GI-ME-N cells have morphologic, chromosomal, and growth characteristics of neuroblasts. They appear to be highly tumorigenic in CD1 nu/nu mice, whereas showing no expression of the $\mathrm{N}$-myc oncogene. Moreover, GI-ME-N cells do not express HLA A-B-C antigens.

\section{MATERIALS AND METHODS}

Patient. M.E. was a 2-yr-old girl diagnosed in December 1984 as group $4 \mathrm{NB}$ according to the Italian staging system (2) or stage IV NB according to Evans et al. (1). At admission she had a large adrenal primary tumor metastasized into the regional lymph nodes and BM. When the BM sample was drawn the patient had elevated levels of vanillylmandelic acid $(45 \mathrm{mg} / 24$ h) and homovanillic acid $(52 \mathrm{mg} / 24 \mathrm{~h})$ in the urine. The tumor responded poorly to chemotherapy (cyclophosphamide, adriamycin, vincristine, peptichemio, cisplatin), and the patient died 11 mo after diagnosis with progressive disease.

Cell culture. GI-ME-N was derived from a sample of infiltrated BM obtained after 6 mo of chemotherapy, containing $85 \pm 5 \%$ 
of UJ13A + cells (18). BM cells were plated directly on a $30-\mathrm{mm}$ diameter Petri dish (Falcon Plastic, Oxnard, CA) in RPMI 1640 medium (GIBCO Europe, Paisley, UK) supplemented with $20 \%$ heat inactivated FCS (GIBCO), glutamine $(100 \mathrm{nM})$, penicillin $\mathrm{G}(50 \mathrm{IU} / \mathrm{mL})$, and streptomycin $(50 \mu \mathrm{g} / \mathrm{mL})$ (complete medium). After 3 days of culture, clumps of adherent cells were present. These cells were washed and the medium replaced. After another $2 \mathrm{wk}$, adherent cells were treated gently with $0.05 \%$ trypsin and $1 \mathrm{mM}$ EDTA in Hanks' balanced salt solution and transferred into $25-\mathrm{cm}^{2}$ tissue culture flasks (Falcon). The medium was replaced every 3-5 days until the cells became subconfluent, at which point they were split. Other NB cell lines (17) (Table 1) were also grown in the same medium as controls. The cells were routinely checked for contaminating microorganisms with negative results. Mycotrim test for mycoplasma (Hana Media, Berkeley, CA) was also negative.

Light microscopy. Phase-contrast microscopy of living cells was carried out with an Olympus T041 inverted microscope (Fig. 1). Cell morphology was also evaluated on a scanning electron microscopy (Fig. 2).

Growth in vitro. Doubling time was determined by seeding 1 $\times 10^{5}$ cells into a $2.5-\mathrm{cm}$ Petri dish (Falcon) and counting with a hemocytometer at 24-h intervals, in three replicate dishes. Cell doubling time was calculated from the best-fit line of logarithmic growth conditions. Cell viability was determined by trypan blue exclusion.

Growth in vivo. Four-wk-old female CD1 nu/nu mice were obtained from Charles River, Italy. The animals were injected s.c. with $3 \times 10^{7}$ cultured GI-ME-N cells in $0.1 \mathrm{~mL}$ of complete medium. SK-N-SH and IMR32 were also injected into control animals. The mice were palpated twice a week to detect tumor appearance (19). The latency or lag time was the time in days

Table 1. Growth of human NB cells lines in 6-wk-old female CDI nu/nu mice*

\begin{tabular}{lcc}
\hline & $\begin{array}{c}\text { Latency time } \\
\text { (days, mean } \pm \text { SD) }\end{array}$ & $\begin{array}{c}\text { Survival time } \\
\text { (days, mean } \pm \text { SD) }\end{array}$ \\
\hline GI-ME-N & $4.6 \pm 0.5$ & $87.3 \pm 28.8$ \\
SK-N-SH & $40.6 \pm 24.8$ & $107.3 \pm 15.0$ \\
IMR32 & $80.6 \pm 25.4$ & $130.0 \pm 31.1$ \\
\hline
\end{tabular}

* Cells were grown in RPMI $1640+20 \%$ FCS and injected subcutaneously as described in "Materials and Methods." necessary to appreciate a 5-mm s.c. tumor. Mice were killed at the time when a $20-\mathrm{mm}$ s.c. tumor was detected (survival time) (Table 1).

Immunofluorescence analysis. Surface antigens were detected with indirect membrane immunofluorescence (18), using the panel of MAb summarized in Table 2 (9). Briefly, adherent cells were scraped off the flasks with a disposable plastic cell-scraper (Costar, Cambridge, MA) and washed twice in complete medium. Fifteen $\mu \mathrm{L}$ of suspension containing $1 \times 10^{6}$ cells were incubated at $4^{\circ} \mathrm{C}$ for 30 min with $15 \mu \mathrm{L}$ of the appropriately diluted MAb. After washing twice the reaction was developed by a second incubation with fluorescein-conjugated goat-IgG antimouse (Coulter Electronics Ltd, Luton, UK) for $30 \mathrm{~min}$ at $4^{\circ} \mathrm{C}$. Cells were then washed twice and observed under a Leitz Orthoplan UV microscope (Leitz Wetzlar, GmbH Wetzlar, Lanh, W. Germany). At least 200 cells per sample were counted and the percentage of stained cells showing either partial or complete ring fluorescence was determined. The same procedure, with minor modification (9), was used to detect neurofilaments, vimentin, chromogranin, synaptophysin, and cytokeratin (Boehringer Mannheim, West Germany) in cells previously grown on multiwell chamber slides (Flow).

Analysis of cytoskeleton. Five Petri dishes, each containing 5 $\times 10^{5}$ cells in complete medium, were prepared. When the cells were confluent, the medium was removed and $3 \mathrm{~mL}$ of PBS were added just before scraping. Cells were then centrifuged at $800 \times g$ for $5 \mathrm{~min}$ and the pellet was resuspended in $5 \mathrm{~mL}$ of extraction buffer $(50 \mathrm{mM}$ Tris $\mathrm{HCl}, 2 \mathrm{mM}$ EDTA, $0.5 \%$ Nonidet P-40 and $1 \mathrm{mM}$ phenylmethylsulphonyl fluoride). The nuclei were eliminated by centrifugation at $500 \times g$ for $5 \mathrm{~min}$. Supernatant, containing cytoskeletal proteins, was withdrawn and ágain spun at $34000 \times g$ for $30 \mathrm{~min}$. The pellet was resuspended in $50-100 \mu \mathrm{L}$ of buffer $(50 \mathrm{mM}$ Tris $\mathrm{HCl} \mathrm{pH} 6.8,1 \%$ SDS, $2 \%$ 2-mercaptoethanol), transferred into Eppendorf tubes, boiled for $10 \mathrm{~min}$, and then spun at $13000 \times \mathrm{g}$ for $2 \mathrm{~min}$. Electrophoresis of $20 \mu \mathrm{g}$ proteins obtained as described above was carried out onto 7.5 or $10 \%$ acrylamide slab gels using a Mini-Protean Dual Slab cell (BioRad Laboratories, Richmond, CA) at $120 \mathrm{~V}$ for 1 $\mathrm{h}$, as detailed elsewhere (9)

Chromosome preparations. The methods for chromosome analysis (20) and GTG-banding (15) have been described in detail.

$D N A$ extraction and analysis. High mol wt DNA was obtained as previously described $(13,21)$. Briefly, DNA $(20 \mu \mathrm{g})$ samples

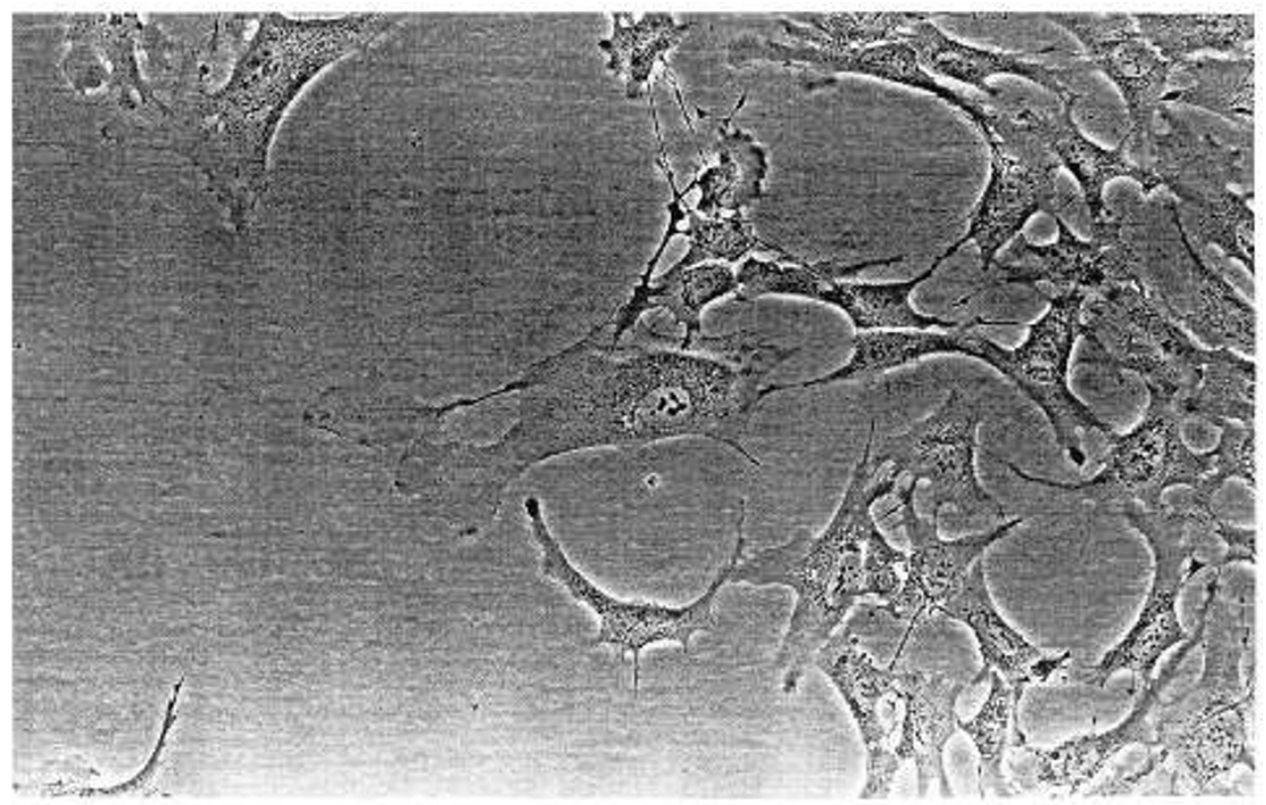

Fig. 1. Morphology of GI-ME-N at the 79th passage (phase contrast $20 \times$ ). Note the differentiated morphology and long neuritic processes. 


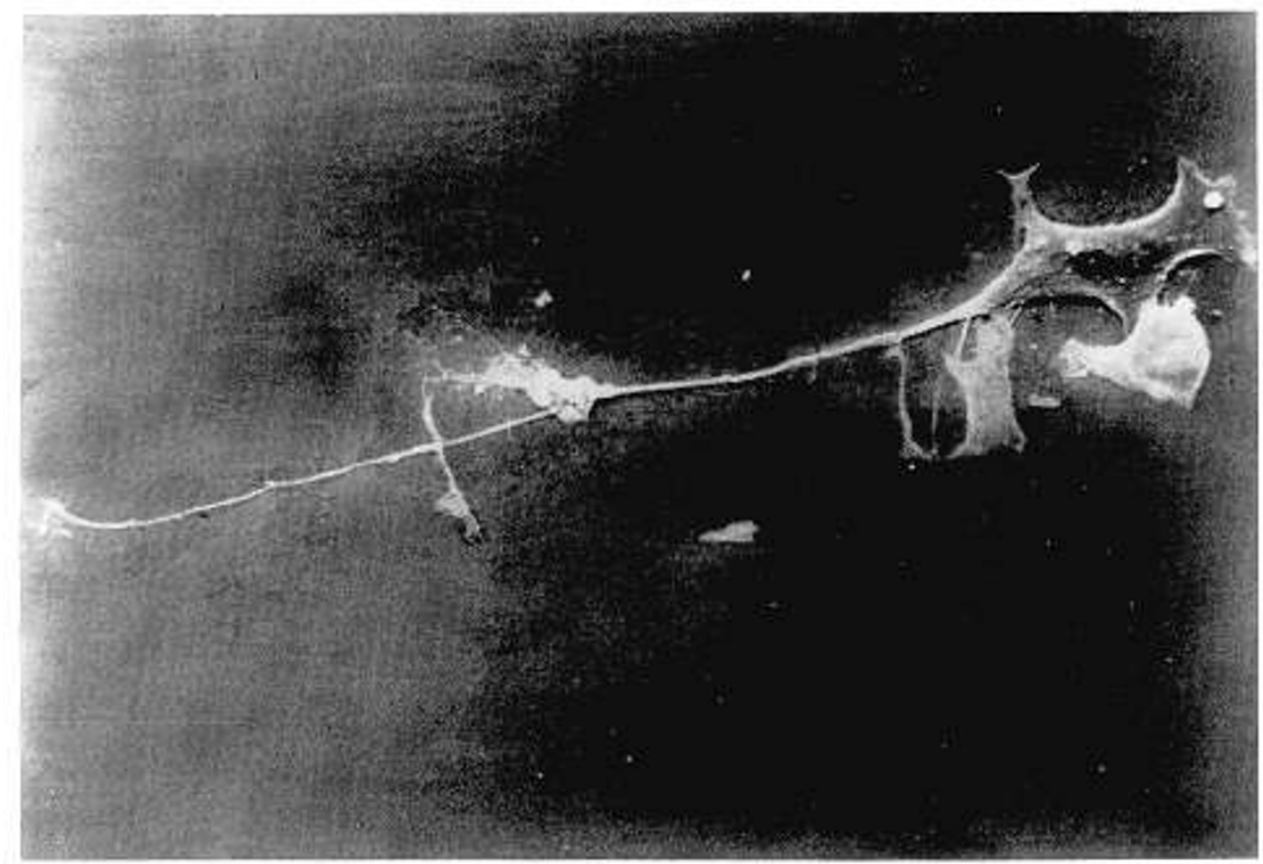

Fig. 2. Scanning electron mycroscopy of a GI-ME-N cell and its neuritic processes. The cell surface appears rather smooth with only few microvilli and blebs. The neurites are usually thin with terminal enlargement.

Table 2. Membrane and cytoskeletal markers of GI-ME-N cells

\begin{tabular}{|c|c|c|}
\hline & Immunofluorescence & Western blot \\
\hline Neurofilaments $68 \mathrm{kD} *$ & - & - \\
\hline $168 \mathrm{kD}^{*}$ & + & + \\
\hline 200 kD* & + & + \\
\hline Vimentin* & + & + \\
\hline Cytokeratin* & - & - \\
\hline Chromogranin* & - & \pm \\
\hline Synaptofisin* & - & ND \\
\hline UJ13At & $30 \pm 5 \%$ & ND \\
\hline HSAN $1.2 \S$ & - & ND \\
\hline $126.4 \#$ & $50 \pm 18 \%$ & ND \\
\hline TEC-CALLA $\dagger$ & $50 \pm 4 \%$ & ND \\
\hline $\mathrm{Ab} 390 \S$ & $64 \pm 4 \%$ & ND \\
\hline $\mathrm{Ab} 459 \S$ & $65 \pm 5 \%$ & ND \\
\hline HLA-1 ( $\beta 2$ microglobulin) & - & ND \\
\hline
\end{tabular}

MAb by * Boehringer, $\dagger$ Tecno Genetics, or kindly provided by $\ddagger \mathrm{J}$. Kemshead and $\S$ C. P. Reynolds. Note: $(-)$ negative; $( \pm)$ weakly positive; $(+)$ positive; (ND) not detected. (IF) immunofluorescence; (WB) western blot.

were digested for $3 \mathrm{~h}$ with $40 \mathrm{U}$ of EcoRI restriction enzyme (Boehringher Mannheim) with $100 \mathrm{mM}$ Tris- $\mathrm{HCl} \mathrm{pH} \mathrm{7.5,50}$ $\mathrm{mM} \mathrm{NaCl}, 10 \mathrm{mM} \mathrm{MgCl}{ }_{2}$ at $37^{\circ} \mathrm{C}$. The DNA fragments were separated by electrophoresis on $0.8 \%$ agarose gel (LE, Miles Scientific, Naperville, IL). The DNA was denatured and transferred on a nitrocellulose filter (Millipore Corporation, Bedford, MA), as described by Southern, with minor modifications (21).

Dot blot analysis was performed using the Hybri-Dot System apparatus (BLR, Bethesda, MD). DNA was mixed to $400 \mu \mathrm{L}$ of $10 \mathrm{mM}$ Tris- $\mathrm{HCl} \mathrm{pH} \mathrm{7.0,1} \mathrm{mM} \mathrm{EDTA,} \mathrm{and} 0.1$ vol of $3 \mathrm{M}$ $\mathrm{NaOH}$. After $1 \mathrm{~h}$ of incubation at $65^{\circ} \mathrm{C}$, the mixture was neutralized by adding 1 vol of $2 \mathrm{M}$ ammonium acetate. Finally, dilutions of denatured DNA were spotted on nitrocellulose filters. The filters were baked for $2 \mathrm{~h}$ at $80^{\circ} \mathrm{C}$ and hybridized with ${ }^{32} \mathrm{P}$ labeled N-myc probe NB 19-21, in the vector pUC-9 (kindly provided by F. Alt, Columbia University, New York, NY) containing 50\% formamide (Serva Feinbiochemica $\mathrm{GmBH} \&$ Co., Heidelberg, Germany), as described $(13,21)$. After hybridization the filters were washed in $2 \times 17.53 \mathrm{~g}$ of $\mathrm{NaCl}$ and $8.82 \mathrm{~g}$ sodium citrate (SSC), $0.1 \%$ SDS at $42^{\circ} \mathrm{C}$ for $15 \mathrm{~min}$ and exposed to Kodak X O-Mat ARX X-ray film (Eastman Kodak, Rochester, $\mathrm{NY}$ ) for $3 \mathrm{~d}$ at $-80^{\circ} \mathrm{C}$.

$R N A$ analysis. RNA was extracted from cultured cells with the acid guanidinium thiocyanate-phenol-chlorophorm method as previously described (22). Northern analysis was performed according to Maniatis et al. (23). The filters were hybridized with ${ }^{32} \mathrm{P} \mathrm{N}$-myc probe with the same experimental conditions described above. Total RNA extracted from control cell lines was also analyzed for the expression of N-myc. The filters were then boiled and washed in $0.01 \%$ SDS, $0.1 \%$ SSC, and hybridized again using ${ }^{32} \mathrm{P} \beta$-actin probe (provided by $\mathrm{S}$. Ferrari, Modena, Italy).

\section{RESULTS}

Growth in vitro and in vivo. GI-ME-N cells show a doubling time of $36 \mathrm{~h}$ and a clonogenicity in semi-solid medium of 826 colonies/well $( \pm 19 \mathrm{SD})$ after $10 \mathrm{~d}$ of culture. Lag time was $4.6 \pm$ $0.5 \mathrm{~d}$ for GI-ME-N and $40.6 \pm 24.8 \mathrm{~d}$ for SK-N-SH. GI-ME-N cells continued to grow in $100 \%$ of the grafted animals $(87.3 \pm$ 28.8 survival time). The survival time for SK-N-SH was $107.3 \pm$ 15.0 days, and for IMR32 even longer (Table 1).

Surface and cytoskeletal markers. Table 2 shows that GIME-N cells express at high levels membrane markers specific for NB cells, UJ13A, 126.4, 390, and 459, while being negative for HLA-1 $\left(\beta_{2}\right.$-microglobulin). Cytoskeletal proteins expressed by GI-ME-N cells investigated by both immunofluorescence and western-blot analysis are summarized in Table 2 . These findings confirm the NB nature of GI-ME-N cells.

Karyotype. GI-ME-N chromosome preparations were examined at the 4 th, 6 th, 21 st, 55th and 79 th passages of continuous culture. Before the last cytogenetic control, the cells acquired a near-tetraploid karyotype, retaining most of the alterations revealed during the near-diploid phase. The modal number was 92 , with a preferential deletion of chromosome $6 q-$ in neartetraploid metaphases. Neither double minutes nor homogeneously staining regions were documented. All karyotype and metaphases had the following markers, some of them were stable and present since the beginning of the culture: $t(1, ?)$; dup (2); dup(4); del (6p); t $(11 ; 17) ;-19 ;+13$ (Fig. 3). Others were only 
present in the earliest passages $(5 q+$ and $12 q+)$, and yet others probably only originated after a certain period in culture $(6 \mathrm{q}-$ and +20 ) (data not shown).

$N$-myc oncogene DNA. N-myc amplification was studied at the 21 st and 55th passages. The DNA restriction analysis showed a 2-kb EcoRI band corresponding to the oncogene N-myc, which

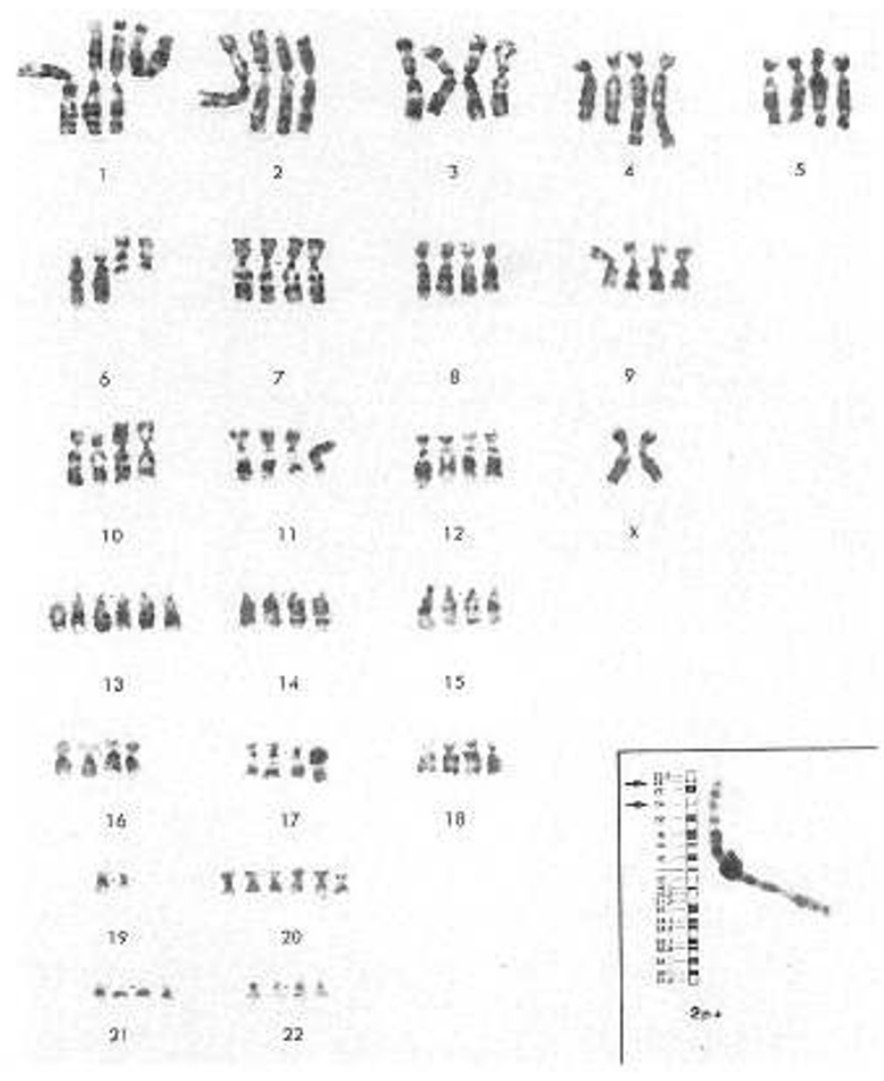

Fig. 3. GTG-banded karyotype of GI-ME-N cell culture: $92, \mathrm{XX},-\mathrm{X}$, $-\mathrm{X},-1,-1,+2(\operatorname{der}(1) \mathrm{t}(1,6))(\mathrm{p} 36, \mathrm{p} 21 ?)),-2,-2,+2(\operatorname{inv} \operatorname{dup}(2)(\mathrm{p} 21 \mathrm{p} 24))$, $-4,-4,+2(\operatorname{inv} \operatorname{dup}(4)(\mathrm{q} 25 \mathrm{q} 34)),-6,-6,+2(\operatorname{del}(6)(\mathrm{q} 13)),-10,-10,+2$ $(\operatorname{der}(10) \mathrm{t}(10, ?)(\mathrm{p} 11, ?)),-11,-11,+2(\operatorname{der}(11) \mathrm{t}(11,17)(\mathrm{q} 13, \mathrm{q} 11)),+13,+13$, $-19,-19,+20,+20$. A high resolution scheme of the chromosome 2 with inverted duplication of the p21-p24 segment can be seen in the lower right panel. was not amplified. DNA from N-myc amplified and nonamplified cell lines were used as control (Fig. 4).

$N$-myc oncogene RNA. N-myc transcript was not detectable in GI-ME-N cell by Northern blot analysis. Figure 5 show the 3.2$\mathrm{kb}$ signal corresponding to the $\mathrm{N}$-myc probe hybridization in eight different human NB cell lines. The Northern analysis appears not to be sensitive enough to detect the signal in either GI-ME-N or SK-N-SH, the only two cell lines carring a single copy of the $\mathrm{N}$-myc. In contrast, all cell lines with multiple copies of the oncogene also express elevated levels of it.

\section{DISCUSSION}

In most cases NB behaves as a highly malignant tumor, resistant and/or relapsing after irradiation and polychemotherapy $(3,5,11)$. However, a number of clinical observations clearly demonstrate that NB has the highest overall rate of spontaneous regression of any malignant neoplasia (3). There are documented cases of spontaneous as well as chemotherapy-associated maturation of NB to benign ganglioneuroma (24). Moreover, infants with stage IV NB, presenting at onset a widely disseminated disease, can be frequently cured, avoiding surgery and/or aggressive polychemotherapeutic regiments (25). A possible explanation of such a peculiar behavior has been suggested by Seeger et al. (6). These authors indicated that at least two biologically distinct neuroblastomas actually exists differing for a molecular alteration involving the $\mathrm{N}$-myc oncogene. $\mathrm{N}$-myc amplified NB would characterize the poor prognosis group of patients. In addition, Reynolds et al. (17), investigating the tumorigenicity of human NB in nude mice, indicated that several so-called human NB cell lines are actually PNET cell lines. Based on this observation, these authors speculate that several metastatic NB having a prognosis as poor as the N-myc amplified NB and showing no amplification or expression of $\mathrm{N}$-myc oncogene, would then need to be reclassified as PNET. This would explain why a large percentage of a single copy $\mathrm{N}$-myc tumors has a very poor prognosis. The in vivo behavior of NB and PNET in nude mice was in fact very different. N-myc amplified, $\mathrm{HLA}-1^{-}$, cell lines show a lag time significantly longer than PNET. However, all single-copy N-myc HLA-1 ${ }^{+}$cells ("false" NB or PNET) show a very aggressive behavior in athymic mice.

We have analyzed more than 100 primary and metastatic NB and established new human NB cell lines $(15,20)$. GI-ME-N derives from the BM of a child with stage IV NB. It shows a single copy of the cellular oncogene N-myc. N-myc mRNA transcript is undetectable with the described assay for both GIME-N and SK-N-SH, possibly due to the relatively short time of

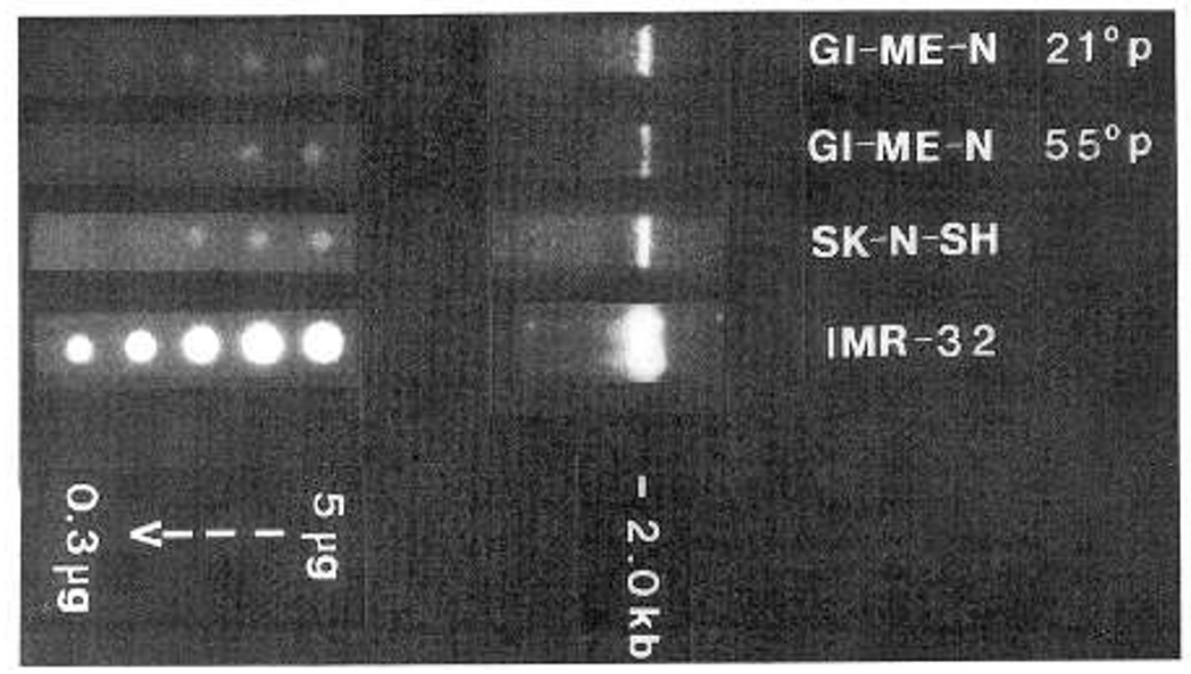

Fig. 4. Restriction analysis of DNA showing a 2-kb EcoRI band corresponding to the N-myc oncogene. Dot blot analysis confirms a single copy of the gene both for GI-ME-N and SK-N-SH, whereas 40 copies of the oncogene are detected in IMR-32 cells. 


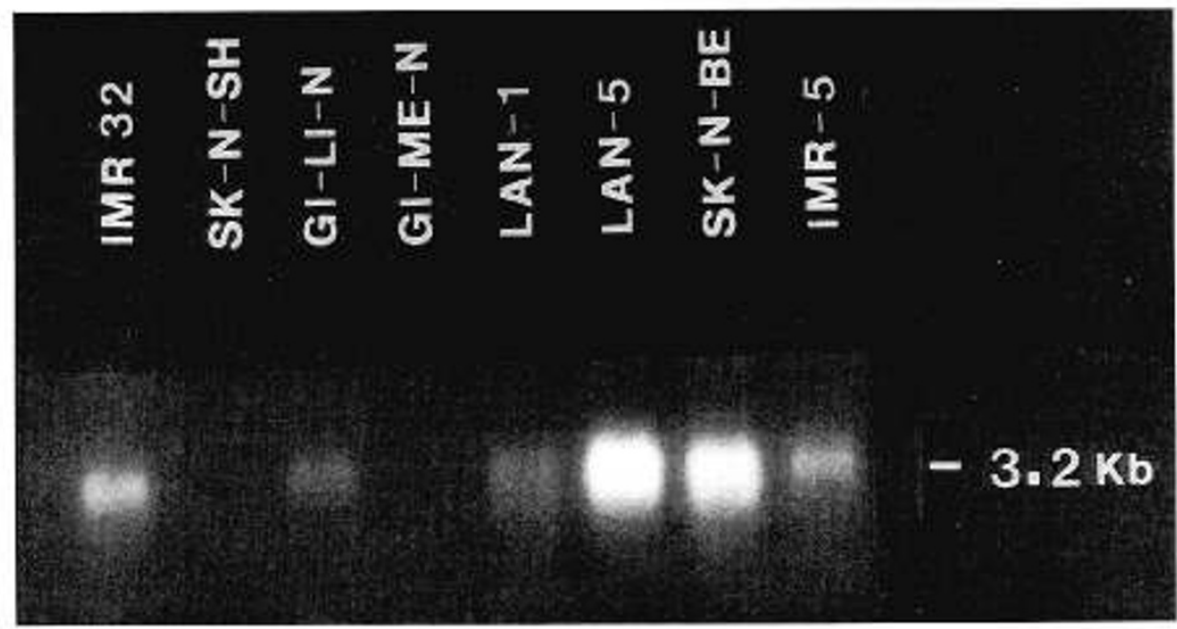

Fig. 5. N-myc transcript of GI-ME-N compared to other N-myc cell lines with variable or undetectable expression of the $\mathrm{N}$-myc oncogene. All control cell lines with amplification of the $\mathrm{N}$-myc also express high level of $\mathrm{N}$-myc transcript. In contrast, the expression of $\mathrm{N}$-myc is undetectable in SK-N-SH cells, which show a single copy of the oncogene.

exposure to x-ray film. However, a different method did not substantially modify this result (26).

Some cytogenetic features appear to be peculiar for NB (20). The partial monosomy of chromosome 1 , which is present in about $80 \%$ of fresh tumors and $65 \%$ of cell lines $(27)$, was one of the more stable and initial anomalies, and very likely occurred in vivo. These data emphasize the close relationship between NB and monosomy of the short arm of chromosome 1, supporting the hypothesis that a gene, or genes, capable of controlling the proliferation of neuroblasts (antioncogene) is, or are, present on this chromosomal segment (28). A duplication of the p21-p24 segment of the chromosome 2 short arm, involving the N-myc oncogene locus (2p23-24) (20), was observed from the 4th passage onward. The derivative chromosome generated by the $\mathrm{t}(11,17)(\mathrm{q} 13, \mathrm{q} 11)$ unbalanced translocation was simultaneously present with both members of the 17 pair and 1 single chromosome 11 in the diploid karyotype. The 17q11-qter segment was, therefore, trisomic, whereas the 11q13-qter was monosomic. Chromosome 17 trisomy is one of the most characteristic secondary anomalies of $\mathrm{NB}$, and seems to play an important role in the progression of this tumor (28).

The expression of surface markers specific for NB cells at different states of malignant transformation (UJ13A, 390, 126.4, 459) $(18,30,32)$ on GI-ME-N cells, strongly indicates the neuroblastoma nature of the cells. This is also confirmed by the absence of HLA class 1 antigen expression, allowing to exclude the PNET nature of the new cell line (17). Changes in the type and amount of intermediate filaments have been shown to accompany neural cell differentiation (33). Immature neurons do not express NF, differentiated neurons express $68 \mathrm{kD}$ and $160 \mathrm{kD} \mathrm{NF}$ and mature neurons express all these proteins (34). Furthermore, because $200-\mathrm{kD}$ NF arises late in neuronal development, and because vimentin is also transiently expressed with NF proteins in neuroblasts (36), their combined presence in GI-ME-N cells may indicate that the malignant transformation occurred in the patient late during the adrenal NB differentiation pathway.

The growth in nude mice as undifferentiated small round cell tumor can be related to the undifferentiated aspect of the cells observed in the patient's original tumor mass. The tumor progression in $\mathrm{nu} / \mathrm{nu}$ was rapid in comparison with SK-N-SH and IMR32, which carry, respectively, a single copy or multiple copies of the N-myc oncogene.

From these results, it appears that GI-ME-N cells can be considered as a new human NB cell model useful in understanding the relationship between the N-myc oncogene and NB cell growth, and an especially appealing system to study the mechanisms of neuroblastoma cell differentiation.
Acknowledgments. The authors thank the following persons for providing us specific monoclonal antibodies and/or NB cell lines: J. T. Kemshead, London, U.K.: C. P. Reynolds, U.C.L.A., Los Angeles, CA; R. A. Reisfeld, La Jolla, CA: R. Revoltella, Rome, Italy; J. L. Bidler, Sloan Kettering, New York, NY. We also thank M. Israel and M. Cooper (NIH, Bethesda, MD) for their helpful criticism in discussing the results.

\section{REFERENCES}

1. Evans AE, D'Angio GJ, Propert K, Anderson J, Hann HW 1987 Prognostic factors in Neuroblastoma. Cancer 59:1853-1859

2. De Bernardi B, Rogers D, Carli M, Maldon E, De Laurentis T, Bagnulo S, Di Tullio MT, Paoloucci G, Pastore G 1987 Localized neuroblastoma. Cancer 60:1066-1072

3. Pritchard J, Kiely E, Rogers DW, Spitz L, Shafford EA, Brereton R, Muller C Wright VM 1987 Long term survival after advanced neuroblastoma. New Engl J Med 317:1026-1027

4. Anderson PM 1988 Augmentation of cell number and LAK activity in peripheral blood mononuclear cells activated with anti CD3 and interleukin 2. Preliminary results in children with ALL and NB. Cancer Immunol Immunother 27:82-88

5. Dini G, Lanino E, Garaventa A, De Bernardi B 1987 High dose therapy and unpurged bone marrow rescue for neuroblastoma with poor prognosis. In: Dicke VA, Spitzer G, Jagannath S (eds). Autologous Bone Marrow Transplantation, Proceeding of the II Intl Symposium. Houston, TX, pp 393-399

6. Seeger RC, Brodeur GM, Shater H, Dalton A, Siegel SE, Wong KY, Hammond D 1985 Association of multiple copies of the N-myc oncogene with rapid progression of neuroblastomas. N Engl J Med 313:1111-1116

7. Shimada H, Chatten J, Newton WA, Sachs N, Hamoudi AB, Chiba T, Marsden HB, Misugi K 1984 Histopathologic prognostic factors in neuroblastic tumors: definition of subtypes of ganglioneuroblastoma and age-linked classification of neuroblastoma. J Natl Cancer Inst 73:405-416

8. Christiansen $\mathrm{H}$, Lampert F 1988 Tumor karyotype discriminate between good and bad prognosis outcome in neuroblastoma. J Natl Cancer Inst 73:405416

9. Ponzoni M, Lanciotti M, Melodia A, Casalaro A, Cornaglia-Ferraris P 1989 Morphologic and phenotypic changes of human neuroblastoma cells in culture induced by cytosine arabinoside. Exp Cell Res 181:226-237

10. Lanciotti M, Cornaglia-Ferraris P, Ponzoni M 1989 Phosphatidylinositol turnover is not a general regulator of neuroblastoma cell differentiation: comparison between two differentiating agents, retinoic acid and $\gamma$-interferon. FEBS Letters 243:285-288

11. Ungerleider RS 1981 Working conference on neuroblastoma treatment trials. Cancer Treat Rep 65:719-723

12. Schwab M, Ellison J, Bush M, Rosenow W, Varmus HE, Bishop JM 1984 Enhanced expression of the human gene $\mathrm{N}$-myc consequent to amplification of DNA may contribute to malignant progression of neuroblastoma. Proc Natl Acad Sci USA 81:4904-4944

13. Tonini GP, Verdona G, De Bernardi B, Sansone R, Massimo L, CornagliaFerraris P $1987 \mathrm{~N}$-myc amplification in patient with IV-S neuroblastoma. Am J Pediatr Hematol Oncol 9:8-10

14. Cornaglia-Ferraris P, Tonini GP 1988 Letter to the editor. Am J Pediatr Hematol Oncol 10:182-183

15. Longo L, Christiansen H, Paulsen P, Cornaglia-Ferraris P, Lampert F $1988 \mathrm{~N}$ myc amplification at chromosome band $1 \mathrm{p} 32$ in neuroblastoma cells as investigated by in-situ hybridization. J Cancer Res Clin Oncol 114:636-640 
16. Reynolds CP, Biedler JL, Syengler BS, Reynolds DA, Ross RA, Freukel EP, Smith RG 1986 Characterization of human neuroblastoma cell line established before and after therapy. J Natl Cancer Inst 76:375-387

17. Reynolds CP, Tomayko MM, Donner L, Helson L, Seeger RC, Triche TJ, Brodeur GM 1988 Biological classification of cell lines derived from human extra-cranial neural tumors. In: Evans AE, D'Angio GJ, Knudson AG, Seeger RC (eds) Advances in Neuroblastoma Research, vol 2, Philadelphia, PA, pp 291-306

18. Kemshead JT, Fitschy J, Goldman A, Malpes JS, Protchard J 1983 Use of panels of monoclonal antibodies in the differential diagnosis of neuroblastoma and lymphoblastic disorders. Lancet $1: 1-8$

19. Cornaglia-Ferraris P, Giovarelli M, Arione R, Bistoni F, Campanile F, Foresta G. Riccardi C 1987 Immunotherapeutic properties of $\mathrm{N}$ - $\alpha$-5-(1,6-dihydro-6oxo-9-purynil)pentyloxycarbonyl-l-arginine (PCF-39) Int J Immunother III $2: 113-121$

20. Donti R, Longo L, Tonini GP, Verdona G, Cornaglia-Ferraris P 1988 Cytogenetic and molecular study on two human neuroblastoma cell cultures. Cancer Genet Cytogenet 30:225-230

21. Tonini GP, Verdona G, Garaventa A, Cornaglia-Ferraris P 1987 Antiblastic treatment does not affect $\mathrm{N}$-myc gene amplification. Anticancer Res 7:729732

22. Tonini GP, Radzioch D, Gronberg A, Clayton M, Blasi E, Benetton G, Varesio L 1987 Erythroid differentiation and modulation of c-myc expression induced by antineoplastic drugs in the human leukemic cell line K562. Cancer Res 47:4544-4547

23. Maniatis T, Fritsch EF, Sambrook J 1982 Molecular Cloning. A Laboratory Manual. Cold Spring Harbor Laboratory, Cold Spring Harbor, NY

24. Knudson AG 1985 Hereditary cancer, oncogenes and antioncogenes. Cancer Res 45:1437-1443

24. D'Angio GJ, Evans AE, Kopp CE 1971 Special pattern of widespread neuroblastoma with a favorable prognosis. Lancet 1:1046-1049

25. Haas D 1988 Complete pathologic maturation and regression of the stage IV-
S neuroblastoma without treatment. Cancer 62:818-825

26. Breit S, Schwab M 1989 Suppression of MYC by high expression of NMYC in human neuroblastoma cells. J Neurosci Res 24:21-28

27. Mitelman F 1985 Catalog of Chromosome Aberrations in Cancer, 2nd ed, Vol 5. Progress and topics in Cytogenetics, Alan R. Liss, New York

28. Knudson AG 1983 Hereditary cancer, oncogenes and antioncogenes. Cancer Res 45:1437-1443

29. Gilbert F, Feder M, Balaban G, Brangman D, Lurie DK, Podolsky R, Rinaldt $\mathrm{V}$, Vinikoor $\mathrm{N}$, Weisband $\mathrm{J} 1984$ Human neuroblastomas and abnormalities of chromosomes 1 and 17. Cancer Res 44:5444-5449

30. Seeger RC, Danon YL, Rayner SA, Hoover F 1982 Definition of a Thy-1 determinant on human neuroblastoma, glioma, sarcoma and teratoma cells with a monoclonal antibody. J Immunol 128:883-889

31. Schultz G, Cheresh DA, Varki NM, Yu A, Staffileno LK, Reisfield RA 1984 detection of ganglioside GD2 in tumor tissues and sera of neuroblastoma patients. Cancer Res 44:5914-5920

32. Rosenblatt H, Seeger RC, Wells JA 1982 A monoclonal antibody reactive with neuroblastomas but not normal bone marrow. Clin Res 31:68A

33. Denk H, Weybora W, Ratschak A, Sohar R, Franke WW 1985 Distribution of vimentin, cytokeratin and desmosomal-plaque proteins in human nephroblastoma as revealed by specific antibodies: co-existence of cell groups of different degrees of epithelial differentiation. Differentiation 29:88-97

34. Shaw $\mathrm{G}$, Weber K 1982 Differential expression of neurofilament triplet proteins in brain development. Nature 298:277-279

35. Scott D, Smith KE, O'Brien BJ, Angelides KJ 1985 Characterization of mammalian neurofilament triplet proteins:subunit stoichiometry and morphology of native and reconstituted filaments. J Biol Chem 260:1973619747

36. Jacobs M, Choo QL, Thomas C 1982 Vimentin and 70K neurofilament protein coexist in embryonic neurones from spinal ganglia. J Neurochem 38:969977 